\title{
3. Threading Many Needles: Ins and Outs of Anthropological Research in Pre-Independence Vanuatu
}

\author{
Ellen E. Facey
}

In this paper I explain the circumstances surrounding research I conducted in the Pacific nation of Vanuatu in the late 1970s, or the New Hebrides/Les Nouvelles Hébrides as it was known at the time. ${ }^{1}$ On applying for an extension of my permit to remain in the New Hebridean community in which I had been living for much of 1978, I was asked to adhere to the limit agreed on prior to my arrival, and to leave within a few days. My reasons for writing about this now are several. For one, it has become more acceptable in the anthropology of recent years to write explicitly with and about the ' $\mathrm{I}$ ' of the writer/researcher/ fieldworker, no longer veiling ourselves in the no-one that is 'One' (as in 'One thinks/can conclude', etc.), in passive verb constructions that create an air of distance and impartiality (such as, 'it appeared to the observer'), and in the various other means used in past decades to mask our own personal features as well as the often personal nature of fieldwork.

That is, however, perhaps only a sufficient cause. The necessary cause has to do with my own personal and professional self. Whether it is a good thing or not, anthropologists still place much emphasis on one another's performance as fieldworkers. In this business it is a precious and also very vulnerable aspect of one's professional persona. I have had the unfortunate experience of finding out what this means at first hand, having been stung by gossip generated by 'colleagues' who came to know one fact about my fieldwork but were blissfully ignorant of any of the details or context behind it. Gossips are remarkably uninterested in details or context, much as tabloids are uninterested in thorough or balanced reporting, so this is not surprising. Nonetheless, in the first stage of my career as a professional, I felt unable to write about these events.

What follows is, first, my tale of arrival in my field site, on the island of Nguna, central Vanuatu, as faithful a representation as I am able to provide of my 'first contact', based on memory and my field diary. I then compare it with similar ones found in the Pacific ethnographic literature. The differences among them lead to consideration of anthropological fieldwork in decolonising and postcolonial situations, and to the specific variables that influenced my experiences

1 I have chosen to use the old name, the New Hebrides, throughout, except where reference is made to postIndependence Vanuatu. 
in the New Hebrides - the experience of arrival and, later, that of departure and also of return or re-entry. Finally, I offer some ideas with the intention of stimulating a discussion of the value of field research within anthropology today and in the future.

\section{Threading many needles}

I flew into the New Hebrides' capital, Port Vila, in March 1978, a 23-year-old post-graduate student eager to prove herself. I then spent what seemed an inordinate amount of time and money languishing in its hotels and restaurants, waiting for local permission to go to my chosen research site, Nguna, an island just off the northwest coast of Efate. I could not calculate the expenditure of mental energy spent in daily visits to the British Residency, and then to the Vanua'aku Pati office, which I had been told by my contact in the Residency, was 'unofficially' but most definitely in charge of visitors to this part of the archipelago. What my graduate advisor, Dr. Michael Allen of the University of Sydney Anthropology Department, had thought would be a straightforward entrée once my visa was approved by the Residency, had turned into a hot, dusty run-around, one that lasted a full month rather than the three or four days Michael had projected. But it was 1978, and the New Hebrides was no longer in the secure, if highly duplicated and confusing, grasp of its two colonial powers, Britain and France. Michael had had a number of successful advisees who had seemingly experienced a smooth passage in various parts of the New Hebrides. But it was not to be the case for me on my journey to Nguna.

I had originally booked to depart Sydney in December 1977, but a scant few weeks before my departure date I received a terse cable from the British Residency's Research Office in Port Vila, saying that my permission to travel to the New Hebrides to conduct research in the Central District had been revoked, indefinitely. Recent 'incidents' and an air of hostility toward Europeans in general had led the Residency to feel that its officers 'could not take responsibility for [my] security'. Not sure what to make of this setback, I contacted Michael who made a number of attempts by phone, eventually successfully, to reach a contact of his in Port Vila for some inside information on what might have caused this reversal. It turned out that there had been an incident in downtown Vila which was being described in some media as a 'riot' and all research permits had been put into limbo, not only mine. We also learned that leaders of the Vanua'aku Pati, an indigenous political independence movement, had declared itself to be the 'People's Provisional Government' of the country on 29 November 1977, a few days before the cable had been sent. Michael's contact claimed that the socalled 'riot' was really nothing more than a few scuffles in the streets of Vila and in some of the small towns on other islands that took place when Pati members 
ran up their new flag. This clarified the situation, but left us hanging as to whether my research would ever be carried out. We would just have to wait and see.

Subsequent news reports confirmed Michael's contact's opinion that the events of late November/early December 1977 were relatively minor. After a few weeks, there were no signs of spreading or increasing violence, so I appealed for reinstatement of my research permit. This was granted and I was able to fly to Vila in late January 1978.

Nonetheless, on my arrival in the capital, officials were at pains to impress upon me two facts: first, that my position was to be a neutral one. Under no circumstance was I to begin making anthropological inquiries, nor to travel outside Vila for such a purpose, until I had been granted permission by the Research Office to do my study in a specific location. Second, the area in which I had proposed working (Nguna Island, in the central District) was considered by all and sundry to be a stronghold of the pro-Independence Vanua'aku Pati. I would have to stay clear of any perception of involvement with their or any other pro-Independence movements. I wondered how much pressure I might be subjected to locally in order to get me to do just the opposite. If Nguna were such a pillar of Vanua'aku Pati strength, what were the chances that I could maintain the neutral stance demanded by the official government?

And then it got worse. My final interview in the Residency was with the government agent most closely involved with Nguna. In respect of his memory, I will leave him nameless. In a quiet, but sombre kind of way, he repeated the warnings I had already been given. Then he added this bombshell, 'Now I'm going to tell you something and, if you should ever repeat it, I shall deny having said it.' My heart sinking, I listened as he explained that Independence was not far off now, and that he and some of his fellows had been for some time providing intellectual, strategic encouragement to the leaders of the independence movement, believing that the colonial hold on the archipelago should and would soon be removed. In light of the fact that the Vanua'aku Pati was the only viable indigenous political party, it was likely to become the first governing party. Therefore, I would have to seek permission from the Pati itself, albeit quietly and unofficially. This was not a suggestion, but a clear instruction. A successful entry and stay in Nguna would depend on obtaining this permission.

So I took myself off to the Vanua'aku Pati's office, and attempted to speak to someone there. For a month I trod a path to their door, to make and then remake missed appointments to be seen by Fr. Walter Lini. Barred from initiating any inquiries in or out of town while my application was reviewed by the Vanua'aku Pati leaders in consultation with their Nguna branch ('Nguna-Pwele 
Working Together in Vanuatu

Cultural Association') representatives, I waited restlessly, spending my slim research funds on a series of increasingly cheap hotels/motels/rest-houses and restaurants.

Eventually I was told that the Pati leaders were awaiting the decision of the Nguna-Pwele Cultural Association representatives. Once that - a positive recommendation - had been received, I was then able to try to make an appointment with Fr. Lini. More time elapsed as the annual Vanua' aku Pati's allmember Congress intervened, but I finally met with the Vanua'aku Pati leader. He was an intimidating presence. Like the Residency officials he, too, gave me a severe lecture and warning regarding what would be acceptable behaviour on my part. But, I was indeed given permission which, in hindsight, I think was extremely generous given the far weightier matters he and the rest of the Pati leaders were dealing with at the time and what may have been to some of the Pati leaders a tempting opportunity to assert their authority by refusing my request in the face of the Residency's approval.

My (officially illegal) Vanua'aku Pati Passport was typed while I waited, a slip of blue paper about 3 inches long, containing my name, occupation, purpose of visit, and permitted length of stay. The last had been shaved down to nine months from the year I had requested, but there was clearly nothing to be gained by querying that, even though my (official and legal) research permit from the British Residency gave me the full year. The irony is that I was never asked at any subsequent time to show my Vanua'aku Pati-issued 'passport', nor even to declare my political sympathies. When on a few occasions the issue did arise in conversation, especially during the national elections of 1979 (during my second field stint), I protested that as a foreigner I was a disinterested spectator and it was inappropriate for me to voice an opinion, and that was always accepted graciously. I suspect that the fact that I attended whatever political rallies or meetings took place on Nguna was taken as silent assent, although I attended them simply as part of my fieldwork, just as I went to church and attended weddings and funerals or trips to market. There were times, though, when I perceived hostility and suspicion as to my motives or that of my 'boss' (advisor) who 'had sent me'. As a young, single woman I was perceived more as someone else's pawn or agent, rather than being myself a person to be concerned about. These instances, however, appeared to have nothing to do with permissions, official or unofficial, but rather with particular individuals' feelings of having being manipulated and cheated in the past by outsiders, or suspicion that the information I was seeking might be used by others, insiders or outsiders, to their disadvantage, for example, in land rights disputes.

The final hurdle to be passed before I could leave town and head to Nguna, was to meet with the in-town representatives of the Nguna-Pwele Cultural Association. In the meeting between myself and two men from the Association, 
in which I explained my purposes once again, I was assured that they had spoken to the chiefs on Nguna, and had 'cleared the path' for me. When the time to leave came, I would send a radio message to a particular person who would meet me and help me arrange for housing.

\section{On the beach}

A few days later...I came out of my reverie with a nasty jolt as the bow ground to a halt against the pebbles of the shallows. The boatman, who had yet to speak at all, began tossing my bags and boxes to the young boys and girls who had come running. The bigger kids caught them and dumped them in a pile up beyond the wet strip on the blinding white sand. As I climbed clumsily over the side of the launch, the littlest of the children stopped short, their faces registering a sort of stunned amazement, as if they had seen a ghost. As I was to find out much later, a few of them were looking at a white person at close quarters for the first time. Judging by their expressions, it wasn't a pretty sight.

Following the children at a more leisurely pace was a man in perhaps his late thirties. He asked, 'Where is Matthew?'2 Startled, I responded in kind, in English, 'Who's Matthew?' At that, he appeared taken aback as I had been at his question, and he turned to address a question in another language to the boatman, who was already back in the launch and trying to re-start its reluctant engine. Over his shoulder the boatman made his reply, succeeded in starting the motor and, without further ado, roared away.

Turning to me, the remaining man said, 'Who are you?'

'My name is Ellen Facey. I sent a message yesterday on the radio saying that I was coming today. It was to Jonathan. Um, I was told that a man named Jonathan was expecting me.'

'Jonathan?'

'Yes! Jonathan. Do you know him?'

'I am Jonathan. Was it your message that was on the radio yesterday?'

'Yes! Yes, I sent the message for you to meet me here this afternoon.'

'Oh.' This was said with a heavy air of disappointment.

'Didn't you get my message?'

'Yes, I heard your message.'

'Oh. Well, is something wrong?'

2 Pseudonyms are used throughout. 
Working Together in Vanuatu

'I thought it was my son, Matthew. I thought the message was from my son, Matthew. I thought he was coming home from school on the launch today.'

Oh, dear. That would be disappointing, to expect your son and find this stranger, a woman, white woman, looking like she meant to stay for some time. Strange indeed.

I glanced toward the bay; the boat was long gone. Clearly a bit of patience and persistence was called for here, to salvage some sense and a plan of action out of this confusion.

'So, you are Jonathan?' Finally, remembering a crucial piece of information that had slipped my mind, I asked, 'You're the school teacher, aren't you?'

He smiled, and seemed relieved to find this common ground, 'Yes, I am the school teacher. That is the school.' He gestured, 'There. Up there. And these are my students.' Still gathered round, but not too near, the children were watching this exchange with keen interest.

'I'm sorry you misunderstood my message and thought your son was coming. But I was told you were expecting to hear from me, waiting for my message.'

This was met with silence. Possibly a bad sign, I thought.

'Uh, I spoke to your sister in Vila.'

'You spoke to my sister? Who?'

'I spoke to your sister, Mercy. The one who works at the newspaper...?'

'Oh, Mercy! Yes, Mercy works at the newspaper.'

'Yes, that's right, that Mercy. She told me she'd spoken to you, that you had a house I could stay in, a house I could rent for a few months.'

A broad smile lit up Jonathan's face: 'You want to stay in my house?'

'Yes, that's right.'

'Well, I don't know. You wait. Wait here.'

And with that, he was gone, striding back across an open field towards the nearby group of cement-block buildings, now taking shape in my mind as the school, complete with flag-pole in the centre of the yard. Some minutes laterduring which time I contemplated the fact that I had neglected to prepare a Plan B in advance - he returned, calling as he came, 'Alright, come! You come!' He said something else to the children, still milling about, eyeing me, and they began to sort themselves and my belongings out according to size and began bearing them away, each with a package or box proportionate to his or her ability. As Jonathan and the first of the children began to recede into the distance, I decided that I had better get going and follow them or be left behind. 
Where exactly we were headed I had no idea, but we were definitely going somewhere, and I would find out soon enough. I brought up the rear of the train of giggling children. As we approached the village I glimpsed a picturesque clapboard building, with a long veranda facing the sea, its white paint little more than a memory.

\section{Modernising images of 'arrival'}

In one way the above vignette is startlingly akin to Bronislaw Malinowski's off-quoted line: 'Imagine yourself suddenly set down surrounded by all your gear, alone on a tropical beach close to a native village, while the launch or dinghy which has brought you sails away out of sight' (1922: 4). It was through this device that Malinowski began the process of establishing himself as the Ethnographer with a capital E, the quintessential empathetic Other, as well as the 'inventor' of anthropological fieldwork as we know it - or think we dotoday (Stocking 1983), until Malinowski's Diary was published, at any rate.

According to Mary Louise Pratt (1986) both Malinowski and, later, his renowned student, Raymond Firth, employed much the same literary conceit, that of the castaway making First Contact with a group of islanders. Thereby they placed themselves as ethnographers in their field of research just as the preceding generations of explorers and military men, as writers, had placed themselves in their fields of exploration and discovery.

Moreover, Pratt, argues, both Firth and Malinowski sought to portray themselves as 'larger-than-life' and twice as 'versatile', a 'subject that...can absorb and transmit the richness of a whole culture' (Pratt 1986: 39). In all, she says, these ethnographers presented themselves as 'anything but the selfeffaced, passive subject of scientific discourse' (ibid.). In her article Pratt goes on to discuss more recent ethnographic portraits, such as E.E. Evans-Pritchard's, David Maybury-Lewis' and, coming to more modern times, those of Marjorie Shostak and others who have encountered San peoples. For each of these and, as well, for all the rest of us who produce ethnographic texts, Pratt asserts that we unavoidably generate self-portraits in how we construct such scenes of arrival and first contact.

In my own case I am struck by the continuity of the beach-side arrival scene found in the writings of my Pacific ethnographic predecessors. The visual image it calls up and the emotional responses the castaway image engenders are ever so familiar. I can scarcely have done anything other than reproduce the trope, it seems. The similarity only holds, however, at the most obvious, most superficial level. The reader cannot read the second section of this paper as the 'traditional castaway' tale, as Pratt describes Malinowski's and Firth's first contact scenes; 
and I cannot be said, like Firth, to have 'show[n] up as a benevolent eighteenthcentury scientist-king' (Pratt 1986: 39). In the first place, this is by no means a first contact, except for the ethnographer as an individual and perhaps some of the children. There is nothing pristine about the situation encountered; the conversation is conducted in the ethnographer's own language. Most of all, there is nothing triumphal about the arrival. This ethnographer is tentative, unsure, definitely not some kind of cool, detached scientist, not a commanding presence or any kind of royalty. In sum, this is not the glorious arrival of some powerful personage; rather, it is a scene of common ground being negotiated. The potential for economic exchange, in the form of rent, is there; yet there is reason to believe that it might be an equal exchange. It is certainly a situation in which the white stranger does not have the upper hand and the outcome, if optimistic, is not at all clear or predetermined.

Mostly, importantly, framing these tales of arrival as we do is misleading. Mine didn't really start 'On the Beach', as I've described it above. It started in Sydney, with permissions, and a cable and conflicting versions of what was happening. The prologue did portend the events to follow.

What is the source of these differences in arrival scenes then and now? It has to do with many differences: different ethnographers; changing eras in the discipline, in gender relations, and in the prevailing international political relations that underlie research in countries other than one's own. It is this last that I wish to address in the balance of this paper. Other readers/writers will analyse my tropes as they will, but the arrival scene I have sketched above is at least a reflection of certain realities that existed in many places in which anthropologists were working in the 1970s and 80s. The differences between the colonial Pacific and the decolonising and newly independent nations of the Pacific are substantial. In part, as a result of this, modern arrival tales will necessarily be unlike previous ones. Our means of gaining access to such fields for study must necessarily be novel, too.

\section{Decolonisation as a fieldwork condition}

Time passed quickly. Unbeknownst to me, it turned out that the house I had rented was for the use of the school teacher, and who should be the appropriate recipient of the rent that I had been paying became an issue. So, after the first two months living on the school grounds, where I had only one neighbouring family, I moved into another house in the village proper, which allowed me to become more involved in everyday matters and events over the next six months.

As the nine-month limit of my 'passport' was approaching, I wrote to the Nguna-Pwele Cultural Association, asking whether I might extend it for another 
month, so that I could stay through the Christmas season, 1978. A few more weeks passed, and the reply came that they would leave the question in the hands of the villagers. It seemed to them that this decision was up to those with whom I had been living since March. That seemed fair and reasonable to me, so I put the matter to the village high chief's 'tongue' (manamena), his assistant who chaired the village council and was his speaker at village meetings. I was asked not to attend the meeting; instead, I submitted a short written description of my work and intentions, in the Ngunese language.

The evening following the meeting the Council Chairman relayed to me the outcome of their deliberations: in view of the nine-month limit permitted by my Vanua'aku Pati 'passport', the village council felt that my stay could not be extended. By that point it had in fact expired, therefore the council had stipulated that I ought to depart within five days from then. They had further decided that, should I wish to return, while the possibility was open for me to do so, I would have to pursue the same avenue of permissions as before. I was also told that I should choose to live in a different village, and that the question of which village would be decided by the chiefs.

It was at this point that I first questioned whether the initial clearance for my arrival (the pledge of having 'cleared the path') had probably not been obtained at all by the local Nguna-Pwele representatives, or perhaps it had not been done in what was perceived by someone as the proper way. Perhaps it had not received assent from all those who felt they ought to have had a say. The other possibility was that some jealousy or irritation may have emerged from perceived advantages or disadvantages of my presence in that particular village. Perhaps there was one or more villager who found my presence tiresome. It might take only one dissenting voice. It might as easily have been, given how politically charged the times were, that the council members simply felt themselves bound to the limitation set on my 'passport', as a reflection of their commitment to the Pati leadership. But I had no way of knowing which, if any, of these possible explanations might be the case. In the end, though, it didn't matter. It was clear that leaving within the requested time-frame was the only option, and this is what I did. I said my goodbyes feeling heavily laden, with both disappointment and gratitude elicited by the gifts that people brought: woven mats; watermelons and other sorts of produce; a garland of frangipani for my hair, and many kind words and hugs.

\section{A return}

My return after eight months away was a complete anti-climax after the rather sudden end to my first field trip. I wondered whether my request for another 
research permit would put me into the same kind of political permission-seeking cycle as I had encountered the first time, and whether I would be denied entry, given what had gone before. To my relief, there was no problem whatsoever. First, in the official view of the British Residency, there had been no trouble reported involving me over the course of my stay on Nguna during 1978, and I had left well within the one year for which they had given approval. At an unofficial level they seemed to be well aware that I had also passed the inspection of the Vanua'aku Pati and had observed their time limit, too. So I received immediate approval to return.

Second, when it came to the Vanua'aku Pati officials, their reaction was much the same. No complaints had come to them and, at that point, they felt that it had become a local decision, as they had stated at the end of my first period of research.

It may be, as I heard from other researchers, that the Pati had made some political capital from my having submitted to their self-declared authority the year before. Albeit in a small way, my case had bolstered their claim to being able to control their heartland of support, the central district. During the months that elapsed since my departure, though, the Pati had reached a higher plateau of political development; so Pati officials gave me to understand that they were unconcerned with my further comings or goings.

At the local village level, I had decided to take the previous decision of the village council at face value. They had raised no objection to my returning, only to my living in the same village, for whatever reason. So I decided to approach one of my primary informants, an elderly man and his wife, pillars of one of the smaller communities down the road from where I had originally lived. When I wrote to them they immediately wrote back, offering to house me. I was glad to have the opportunity to live with a family, which included their two young grandsons, rather than living on my own as I had before. Their village was also only a 30-minute walk from my former village, so I was able to visit and maintain relations with people there as well as in my new location. Also, the new village was only a quarter the size of the first village, and considerably less affluent, so it provided a contrast in a number of ways that were very informative. In particular, in terms of village politics, my new location had fewer formal decision-making structures because they had chosen not to institute a new style of village council such as the first village had. Therefore, while much of the everyday business of village life - decisions, disputes, interpersonal problemswent on in the first village in camera within committees, in the second, all village business was conducted in the public weekly meeting of the whole.

In fact, knowing that I had been asked not to reside again in the first village, those of the second appeared to take particular pleasure in making sure that I was party to all discussions in their village (in keeping with a strong inter-village 
rivalry). As a result, I saw and heard much more of the dynamics of the kinds of things that I had not had the opportunity to see or hear before, for example, the trial of an allegation of adultery and the resolution of land boundary disputes. This allowed me to shine the light of contrast on some features of the first village, as well as to fill gaps in my ethnography that had been created by the more closed atmosphere and political structure of the first village.

\section{Ethics of access in changing circumstances}

In the years of my fieldwork there, 1978 to 1980, the New Hebrides was in a state of transition, from colony and Condominium to nation, as Vanuatu. This transitional era might be said to date from the 29 November 1977 declaration of a People's Provisional Government by the Vanua'aku Pati. From that time on researchers were subject to a series of levels of government, official and unofficial, national and local. Up until then, access by foreign researchers had been virtually unlimited, with relatively perfunctory examination of credentials and intentions by one or other of the foreign governments. Thereafter, the prototypical field-research situation had prevailed, wherein the anthropologist had but to arrive on the island of her/his choice and proceed to work through a personal network grounded in the asymmetrical power relation between Native and Western 'Other' and developed by assiduous management of material goods: money, Western medicines and luxury items, use of a boat or truck, and so on. In other words, having passed a cursory inspection for a visa, once in situ, the anthropologist had been subject only to the vagaries of local opinion.

Such situations certainly could be a source of considerable difficulties, especially in densely populated and socially diverse areas, or equally, in remote, ultraconservative areas. Yet this is a far cry from the kind of complex situation researchers walked into in the New Hebrides when I did. It was a sign of the times that I was required to pass muster at four different political levels, each with different degrees of authority and ability to enforce their decisions. The strategy I employed was to cooperate fully and straightforwardly with representatives at all these levels. While I was concerned at the time with the resultant delays and expenses involved, and the multiple examinations of my plans and personal politics, this was compelled by that acutely sensitive context, especially in the part of the country in which I was interested. To do otherwise would have been to deny and disrespect existing forces, be they official or otherwise.

Having had this experience it troubles me when I hear, on occasion, that researchers have turned to sneaking into countries where the research approval process may be a lengthy one with a stringent and perhaps costly review process. Entering 'through the back door', either without a visa or on a tourist 
rather than a research visa, while fully intending to conduct research, is a kind of subversion of the structures in place in other countries - whatever one might think of them - that is dangerous and foolish. The international image of the anthropologist is already poor among some groups without further tarnishing it through open displays of cultural arrogance.

Perhaps in such situations we should do more of what we claim to do bestcomparative research, using existing materials. We should also certainly do more of what recent researchers in Vanuatu are doing: collaborative, applied research. When I finished my research and completed my dissertation, which of course was in answer to my own purposes of obtaining a post-graduate degree in anthropology, I made the decision to try to render my research results in such a way as would be of interest and value to the people of Nguna, most particularly to those who had helped and encouraged me the most. What would be of greatest value and benefit to them? In my case it was not hard to identify what to do. Many of the men who had put in the most hours to help me understand their traditions were very elderly. Even by 1982, as my dissertation was heading out for binding, several of Nguna's Elders best known for their knowledge of stories and other types of oral knowledge had already passed away. I knew beyond a shadow of a doubt what would honour their memory and what would be appreciated by those who remained, and hopefully also their families and younger generations, too; a compendium of their stories in their own language. Using techniques available from studies of oral literature, particularly the work of Dennis Tedlock and Peter Seitel, I tried to re-create/re-present the experience of those people's stories as lived performances - their voice, their tones, the feelings they elicited from moment to moment. This I believed would be a far more satisfying legacy and tribute than any other scholarly product that I might create.

It was not easy to 'sell' even academic publishers on the idea of a bilingual book, one of those languages being spoken by a maximum of 3,000 to 4,000 people in one 'remote' part of the world. The book was written primarily for the Ngunese audience, so ultimately I went with a small Canadian university press because they were the first to agree to publish the volume as written, in particular with all the texts in both English and Ngunese, the complete text in Ngunese coming before the English to avoid the distraction of inter-linear translations. Providing the texts in English fulfilled a secondary purpose of opening the reading of the texts to a world-wide audience, while at the same time making the book more useful for teaching/learning English, or Ngunese. Likewise, the introductory chapters aimed at the anthropological audience were kept to a minimum so as not to overshadow the texts themselves. I made a whole series of such decisions and, not surprisingly, I have had complaints from everyone: an Appendix of inter-linear translations and glossary are not enough 
for the linguists; there is not enough ethnographic detail for the ethnographers. One reviewer actually asked what could possibly make me want to spend so much time trying to faithfully re-present all the details of different speakers' style, stress, intonation, non-verbal gestures, etc. in every text rather than analysing their content. Everybody, except the Ngunese, has not been satisfied. But that's OK, because all I have had from Ngunese people-people I know and people I've never met, by mail, in two languages, and most recently by e-mail, also in two languages - are notes of appreciation and requests for additional complimentary copies. That has made it all worthwhile.

Nguna Voices was special and novel when it came out in the later eighties. But already it is the past. The future may be collaborative, community-driven research. As long as it produces results that have value for local people, while not at the same time creating inequalities - that seems like a good thing. It is now fair to say that the researcher who fails to return something to the people with whom she/he has worked is unlikely to receive approval for a return engagement. Indeed, following from recent and ongoing changes to Canadian research ethics guidelines with Aboriginal peoples, the researcher who does not engage potential subjects of research as partners, with outcomes and benefits to those communities agreed to in advance, will not be able to do research. And appropriately so, in my view.

\section{References}

Facey, Ellen E., 1988. Nguna Voices: Text and Culture from Central Vanuatu. Calgary, Alberta: University of Calgary Press.

Malinowski, Bronislaw, 1961 [1922]. Argonauts of the Western Pacific: An Account of Native Enterprise and Adventure in the Archipelagoes of Melanesian New Guinea. New York: E. P. Dutton \& Co., Inc.

Pratt, Mary Louise, 1986. Fieldwork in common places. In Writing Culture: The Poetics and Politics of Ethnography, ed. James Clifford and George E. Marcus, 27-50. Berkeley, California: University of California Press.

Stocking, George W. Jr., 1983. The ethnographer's magic: fieldwork in British anthropology from Tylor to Malinowski. In Observers Observed: Essays on Ethnographic Fieldwork, ed. George W. Stocking, Jr., 70-120. Madison, Wisconsin: University of Wisconsin Press. 